\title{
Autologous Bone Marrow Transplantation
}

National Cancer Institute

\section{Source}

National Cancer Institute. Autologous Bone Marrow Transplantation. NCI Thesaurus. Code C15395.

Bone marrow transfer in which the patient is his own donor. Bone marrow is removed prior to bone marrow ablation treatment and then returned to reconstitute the hematopoietic system. Prior to reinfusion the bone marrow is often treated to purge it of residual tumor cells. 